UDC 821.163.41-31.09 Basara S.

https://doi.org/10.18485/ms_zmskij.2020.68.1.13

Др Јованка Д. Калаба

\title{
ЛИРСКО-МЕЛАНХОЛИЧНИ ЈЕЗИК У ПОСТМОДЕРНИСТИЧКОМ PОМАНУ: ОБЈАВА БРОЈА 49 ТОМАСА ПИНЧОНА И ФАМА О БИЦИКЛИСТИМА СВЕТИСЛАВА БАСАРЕ
}

Полазећи од значајног места које су у стваралачком процесу одређени теоретичари постмодернизма давали носталгији и меланхолији, рад истражује пре свега могућност, а затим и функцију лирско-меланхоличног израза у романима Објава броја 49 Томаса Пинчона и Фама о бициклистиима Светислава Басаре. Кроз пародичну самореференцијалност постмодернистичког језика која преиспитује људско постојање у постмодерним околностима, промаљају се лирски фрагменти чији поетски језик реферише на наративе из књижевних епоха који су могли да буду непародични израз надахнуте аутентичности. Недостатак литературе на тему лирско-меланхоличног израза у постмодернистичкој прози сведочи о његовој скрајнутости, која није неочекивана имајући у виду да пародично деконструисање реалистичког представљања, што постмодернистичка књижевност у самој својој бити ради, оставља невелик простор за поетику меланхоличног и лирског. Из тог разлога овај рад поставља питање откуда у самореференцијалним, пародичним романима као што су Објава и Фама једна сасвим покретачка туга и сузе главне јунакиње Објаве Едипе Мас пред уметничком сликом или меланхолија у писаним траговима средњевековног краља Карла Ружног и капетана Квинсдејла у Фами. Лирско-меланхолични израз, иако на први поглед неприметан у својој расутости, може да се чита као вид супротстављеног наратива самореференцијалности, и као такав представља веома важан и недовољно истражен елемент постмодернистичког језика. Рад ће на примеру ова два романа показати да се лирско и меланхолично у постмодернистичком роману јављају, често јетко и са срџбом очајника, као опомена о нестајању духовности из вредносног система савременог појединца.

Кључне речи: постмодернизам, роман, носталгија, меланхолија, лирско. 
1. Увод. Способност метапрозног коментара, „интензивна самосвест (и теоријска и текстуална) о чину приповедања у садашњости о догађајима из прошлости, о вези између садашње радње и одсутног прошлог објекта те радње" (НuтснЕоN 2001: 71), једна је од главних особина постмодернистичке књижевности, која не оставља никакав или веома мали простор за естетско уживање у књижевном делу. Шта се дешава, међутим, када та „интензивна самосвест“" изостане, када се у делу постмодернистичке књижевности остави простор за ,задовољство и поистовећивање”, о којима говори Алтијери у свом есеју The Powers and the Limits of Oppositional Postmodernism, а даље разматра Бертенс у свом делу The Idea of the Postmodern? Постоје, дакле, поетичке „пукотине“ у самореференцијалном дискурсу постмодернистичког романа, и, ако постмодернистичка књижевност пре свега представља “[п]ародичну игру са оним што бисмо могли назвати симболима реалистичког представљања"2 (IDEм 2001: 89), откуда онда једна, чак покретачка, туга Едипе Мас, и њене сузе пред пред триптихом Bordando el Manto Terrestre сликарке Ремедиос Варо у Објави броја 49, или меланхолија у записима краља Карла Ружног или капетана Квинсдејла у Фами о бициклистиима? Рад се бави управо овим аспектом постмодернистичке књижевности која, иако самореференцијална и артикулисана на начин који одучава читаоца од поистовећивања и „уживљавања“ у текст, својом лиричношћу производи снажан, меланхоличан доживљај. Рад отвара тему могућности, места и функције лирско-меланхоличног израза у постмодернистичкој прози бавећи се траговима и пореклом непародичног, лирског израза, фрагментарно распоређеног у тексту Објаве броја 49 и Фаме о бициклистиима, тематским и формалним обележјима тог израза у два романа, и начином на који лирско-меланхолични фрагменти у себи истовремено поседују и метапрозни, самореференцијални коментар и изразит поетски набој.

Иако је, изненађујуће, литература на ову и сродне теме скоро непостоjeћа, значај расутог, пародијом скоро имобилисаног и неприметног лирског језика у тексту Објаве броја 49 и Фаме о бициклисиимма се наметнуо као контранаратив самореференцијалног језика и скрајнут, али важан део постмодернистичког језика. Меланхолично и лирско се појављују у дискурсима који опомињу, неретко јетко и са агресијом очајника, на нестанак духовности као идеје центра из живота (пост)модерног појединца. Овај рад кроз анализу одабраних текстуалних одломака из оба романа указује на елементе који се налазе у бити синтаксичко-семантичких процеса који производе лирско, и то кроз препознавање и тумачење ефеката језичких слика, стилских и реторских фигура као и врста речи (с акцентом на придеве) и њихове важности као маркера стила, затим распореда речи у реченици, понављања и

1 „In both historiographic theory and postmodern fiction, there is an intense self-consciousness (both theoretical and textual) about the act of narrating in the present the events of the past, about the conjunction of present action and the past absent object of that agency."

2 „Parodic play with what we might call the trappings of realist representation..." 
ритма, и дужине реченица и (не)употребе везника, организације зависних унутар сложених реченица, и њихов укупан утицај на прогресију мисли и садржај поруке.

Човеков „излазак из себе, али не у трансцедентно већ у чисто ништавило“ (БАСАРА, Енигма постмодернизма, 2010-2011: 61) као велика тема књижевности прожима оба романа. И кроз Пинчонов и кроз Басарин роман провејава језик туге изазване празнином модерног постојања и наметањем духовност као застареле, неважне, у најбољем случају другоразредне категорије. Оба романа објављују испражњеност (пост)модерног света од сакралног искуства, а њихови јунаци осећају исту меланхолију за изгубљеним, недохватним смислом, и за „директном, епилепсичном Речју, криком који би могао да поништи ноћ“" (Пинчон 1992: 110). И поред свеприсутних пародичних поступака који преиспитују постмодерно стање људског постојања и свести, снажни поетски фрагменти одзвањају лиричношћу која евоцира књижевне епохе и наративе који су могли бити непародични и изнедрити надахнут, аутентичан израз. Важно је напоменути да се под лирским овде не подразумева језик који је „неоконзервативно носталгичан” (HUTCHEON 2001: 13), носталгичан у односу на прошлост коју представља и коју имитацијом покушава да обнови и установи у савременом контексту, већ, напротив, језик који је у сагласју са садашњим тренутком - тиме и са постмодерном пародијом - и самим тим и аутентичан у својој лиричности.

У свом делу The Idea of the Postmodern, у поглављу које се бави постмодернистичком деконструкцијом, Бертенс указује на Алтијеријеву „изненађујућу одбрану политичког потенцијала отворено миметичке (и комформистичке) уметности, толико презрене од стране теоретичара левице“. Таква уметност, истиче Алтијери, иако утемељена на „истински буржоаској естетици“3 (ALTIERI 1990: 468) не мора увек бити сасвим подређена естаблишменту нити подразумева „одбацивање свих критичких функција уметности“4 (IDEM: 475). Напротив, лирски језик омогућава задовољство у тексту и у том смислу је веома важан, иако његов значај, поред горућих питања као што су проблем конзумеризма и неопходност политичког опозиционарства у књижевности и уметности, олако бива умањен. Присуство лиричности се такође види и као политичко и субверзивно, јер „нас подсећа на стања која наше политичко деловање у уметности жели у људима да побуди, вођено идеалом да уметност може да ублажи психолошко насиље које спровођење тих политичких циљева у дело неминовно прати“5 (IDEM: 468-477).

За Бертенса је Алтијеријев став о значају лиричности у постмодернистичкој књижевности и уметности „изненађујући“, имајући у виду до које

3 ,... a frankly bourgeois aesthetic..."

${ }^{4}, \ldots$. does not require rejecting all critical functions for art..."

$5, \ldots$.reminds us of the personal states that we want our political commitments to make possible for greater numbers of people, while also holding out the promise that art can temper the psychological violence inherent in formulating and pursuing those political goals." 
мере су теоретичари културе и књижевности сагласни у томе да је постојање било чега аутентичног у савременом свету, а поготово емоција, у најмању руку проблематично. Фредерик Џејмсон, у своме делу Postmodernism, or the Cultural Logic of Late Capitalism, говори о феномену слабљења афекта у постмодерној култури, повезујући га донекле са „слабљењем велике тематике времена и темпоралности високог модернизма“"6 (JAMESON 1991: 16). Џејмсон каже да би било „нетачно сугерисати да су из новије слике сваки афект, осећање или емоција, и сва субјективност потпуно нестали“, али да је оно што нова епоха нуди ,једна врста чудног, надомешћујућег, декоративног усхићења"7 (IDEM: 9). Џејмсон види корене овог догађања у виђењу појединца не више као аутономне индивидуе која поседује своју личну субјективност, већ као друштвене, политичке и културне конструкције коју друштво обликује у идеолошки прихватљиву индивидуу; у таквом контексту, каже Џејмсон, „не постоји више сопство које би могло да осећа““ Човек као „културни производ“ није потпуно лишен осећања, већ су та осећања „које би било боље и прецизније звати ,интензитетима“ (израз Жан-Франсоа Лиотара) сада слободно плутајућа и имперсонална, лако преплављена једном посебном врстом еуфорије“"8 (IDEM: 16).

Едипа Мас, јунакиња тужно-пародичне потраге за Тристером у Објави броја 49, такође осећа ово слабљење, „неки осећај ублажавања, издвајања, [...] одсуство интензитета, као кад се гледа филм који је тек једва уочљиво неизоштрен а оператор одбија то да среди“ (Пинчон 1992: 15-16). Она, међутим, трагом најхрабријих књижевних јунакиња из неких других епоха, одолева искушењима овог слабљења, одбијајући лекове доктора Хиларијуса чија жртва постаје и њен муж Мучо Мас. Са свешћу о томе да се слика света испред њених очију необјашњиво замагљује, остављајући је на месту на ком стоји сама и изгубљена за друге и друге изгубљене за њу, она не одустаје од покушаја да слику ипак изоштри. У Црном суниу, у делу који се бави Маргерит Дирас, Јулија Кристева, говорећи о меланхолији и постмодерном изазову, истиче да је ,постмодерна ближа људској комедији него неизмјерно дубокој нелагоди“, као што је, у крајњем случају, меланхолија, истичући отежаност доживљаја ,дубоке нелагоде“ у постмодерном добу, али ипак закључује оптимистичним питањем: „Нови заљубљени свијет жели да исплива на површину у вјечном повратку историјских и духовних циклуса. [...] Зар се зачуђеност психичког живота не одражава послије свега

${ }^{6}$ „The waning of affect, however, might also have been characterized, in the narrower context of literary criticism, as the waning of the great high modernist thematics of time and temporality..."

7 ,...a strange, compensatory, decorative exhilaration...”

$8, \ldots$ there is no longer a self present to do the feeling. This is not to say that the cultural products of the postmodern era are utterly devoid of feeling, but rather that such feelings - which it may be better and more accurate, following J.-F. Lyotard, to call "intensities" - are now freefloating and impersonal and tend to be dominated by a peculiar kind of euphoria..." 
у тим смјењивањима одбрана и падова, осмијеха и суза, сунаца и меланхолија?““ (КристевА 1994: 314). Кристева говори о једној напетој дијалектици коју производе смене историјских и духовних циклуса а који ће у једном тренутку неминовно довести до другачијих околности од оних које стварају Џејмсоново слабљење ефекта. Веровање у ову промену је такође веровање у то да постмодерни изазов није у томе да се меланхолија или било које друго осећање коначно прогласи немогућим, већ да се, и кроз књижевност, постмодернистичка пародија и самореференцијалност ставе у продуктивну опозицију са лиричношћу.

2. ТЕОРИЈСКО-МЕТОДОЛОШКИ ОКВИР: ПОСТМОДЕРНИСТИЧКИ ОСВРТИ НА НОСТАЛГИЈУ И МЕЛАНХОЛИЈУ КАО СРЖНО ПРИСУСТВО У КРЕАТИВНОМ ПРОЦЕСУ

2.1. ЛИНДА ХАЧИОН: НОСТАЛГИЈА КАО ЖАЛ ЗА АУТЕНТИЧНОШЋУ. У есејy Irony, Nostalgia, and the Postmodern, Линда Хачион се бави носталгијом као врло важним сегментом постмодерне културе и књижевности. Хачион одваја ескапистичку, „регресивно ревивалистичку“ носталгију која је, Џејмсоновим речима, „очајнички покушај да се присвоји прошлост које више нема“9 (JAMESON 1991: 19) и која тежи ка томе да хигијенски одстрани непожељне елементе садашњег културног и друштвеног стања посезањем за културним моделима и наративима из прошлости, од носталгије која је аутентично утемељена у садашњем тренутку и одражава истинско незадовољство оним што друштво и култура у садашњем тренутку представљају. Таква носталгија као своју компоненту има и иронију, а самим тим и пародију која је, по Хачион, уско повезана са иронијом и критичком, полемичком оштрицом ироније која производи друштвени коментар.

Истичући да је носталгија увек структурално сачињена од два временска раздобља: од неодговарајуће садашњости и идеализоване прошлости ${ }^{10}$ (HutcheON, 2000: 198), Хачион подвлачи значај друштвено-критичке димензије носталгије. Већ смо споменули да Алтиери види лиричност као политичку у том смислу да емотивна стања која лиричност изазива делују као противтежа агресији политичког деловања. Хачион такође види носталгију као појаву у којој се прожимају емоција и политика, и у том смислу је пореди са иронијом. Хачион објашњава иронију као нешто што се појединцу „деси“ када се два значења, једно изречено и друго неизречено, нађу заједно, и тај сусрет произведе одређену критичку оштрицу11 (IDEM: 199). Носталгија у блиску везу доводи два временска тренутка, прошлост и садашњост, што опет доводи до закључка о политичности носталгије, имајући у виду

\footnotetext{
9 ,...the desperate attempt to appropriate a missing past..."

${ }^{10}, \ldots$ structural doubling-up of two different times, an inadequate present and an idealized past."

${ }^{11}$,... irony "happens" for you (or, better, you make it "happen") when two meanings, one said and the other unsaid, come together, usually with a certain critical edge."
} 
да почивају на специфичном упаривању наратива из различитих временских епоха које производи друштвени коментар.

Истовремена ироничност и носталгичност постмодернистичког дела је увек показатељ „коначне немогућности уживања у носталгији“12 (IDEM: 205), чиме су и сама носталгија, њено кретање и сврха, иронизовани. Трагови и знаци иронизирања и пародирања поетско-лирског носталгичног израза присутни су у Објави броја 49 и у Фами о бициклистиима. Сваки меланхолично-носталгични окрет и у Објави и у Фами обично се завршава пародичном иронизацијом тог поступка. Објава, као текст који је по својим тематско-формалним одликама у многоме модернистички, има снажан лирски потенцијал заснован на метафори, поређењима и описним придевима замагљеног, „одложеног“ значења; Фама, с друге стране, као парадигматски постмодернистички текст, дугује свој меланхолични набој тексту који обилује понављањима, контрастима и инверзијама који реченици дају поетску наглашеност, о чему ће бити речи даље у тексу. У оба романа „изражени хуморни слој ублажава егзистенцијалну језу“ (СтАнолевић 2010-2011: 81), међутим, „у самом корену тог хумора“, истиче Марјан Чакаревић говорећи конкретно о Басари, „као што се у основи његовог надреалистичког претка крију романтичарски отац велтшм(е)рц и мајка иронија, налази се лирскомеланхолични покрет, који - и то је од пресудне важности за разумевање целокупног Басариног дела - јесте основно осећање света овог писца. Сви они који су [...] се склањали од света због туге чији разлози нису никада објашњени, [...] то су у ствари они којима Басарина проза пружа јединствено уточиште" (ЧАКАРЕВИЋ 2010-2011: 186)

Примера ради, главна јунакиња Објаве хумористично иронизује сећање на своје потресне сузе испред триптиха Bordando el Manto Terrestre и промишљање свог места у свету у ком се налази, схватајући да је

сасвим нежно завела себе у чудновату, рапунзеловску улогу замишљене девојке која је некако, готово магично, постала заточеница међу боровима и сланим маглама Кинерета, у потрази за неким ко ће рећи: Хеј, распусти своју косу. И кад се испоставило да је то Пирс, она је весело повадила шнале и папилотне и коса јој се сјурила као шапутава, нежна лавина, и тек кад се Пирс узверао до пола, њена дивна коса се претворила, помоћу неке страшне враџбине, у велику непричвршћену перику, и он се сручи доле, право на дупе (Пинчон 1992: 16).

Такође, у Фами, краљ Карло Ружни завршава повест о свом краљевству са сетом, али и усред опроштаја од свог читаоца текст не пропушта прилику за хумористични метапрозни коментар:

Гросман је заспао. Видим то по одсуству његовог присуства. Иако нисам уморан, ускоро ћу заспати и ја. Али пре него што и ја склопим очи, услед свеопште конкретизације претворене у две странице неке

$12, \ldots$ final impossibility of indulging in nostalgia” 
књиге, осврнућу се и још једном погледати тај врли нови свет. Taj danse macabre. Круг без излаза. Circulus vitiosus (БАСАРА 2013: 301).

Са постмодернистичке тачке гледишта, закључује Хачион, свест о овој врсти ироније не би требало да представља штит од моћи коју носталгија поседује. Политичка моћ носталгије је увек у спрези са иронијом, јер само таква има способност да произведе друштвени коментар не само о садашњем тренутку, већ и за тренутком из прошлости за којим тежи. Као таква, лирска носталгија у постмодернистичкој књижевности се окреће ка прошлости, чак и ка миметичком представљању и могућности естетског уживања на један не-регресиван, продуктиван начин.

2.2. О СМИСЛУ МЕЛАНХОЛИЈЕ РОМАНА ГВАРДИНИЈА: „КОНСТИТУЦИОНАЛНА ТУГА“ КАО КОРЕН СТВАРАЛАЧКОГ ПРОЦЕСА. Постојање свеТа, стремљење ПојеДИНца за спознајом смисла постојања али у исти мах и схватање да је то стремљење узалудно, је за немачког филозофа и теолога Романа Гвардинија у самом корену меланхолије. Гвардини види меланхолију као „метафизичку празнину“ узроковану схватањем коначности ствари као недостатка света, који је „разочарење за душу, за срце које жуди за апсолутом“, које „се шири и постаје утисак велике празнине [...] И нема ничег што би било вредно да се човек њиме бави“ (ГвАРдини 2006-2007: 137). Међутим, као и Кристева, о чему ће бити речи даље у тексту, Гвардини истиче да поред речи „о мучном, негативном, о патњи и о разорном елементу меланхолије“ мора се говорити и нечему другом, што се назире „из све те беде“ а што је „драгоцено и племенито“:

Та тежина, о којој смо говорили - то је била полазна тачка ка дубљем продирању у средиште феномена - даје свеколиком чињењу особиту дубину и пуноћу. [...] Величина, крајња и стварна величина, није могућа без тог притиска ... без оне такорећи конституционалне туге, онога што Данте назива „la grande tristezza“, која израста, не из неког посебног повода, него из самог постојања (IвID.).

Гвардини сугерише да је бављење филозофским питањима коначности и смисла човековог постојања немогуће без егзистенцијалне туге, коју види као пресудно „оптерећење“ у промишљању феномена. Ово промишљање постаје истински плодоносно „кад притисак попусти, кад се тај унутрашњи затвор отвори“ после чега се успоставља ,јасноћа погледа и она непогрешивост у уобличавању дела““(IBID.).

Непознати преписивач повести капетана Квинсдејла у Фами о бищиклистиима, након што се „скрхан необјашњивом потиштеношћу и умором“ осамљује далеко од Лондона, проналази мистериозну повест у запечаћеној боци насуканој на обали океана и, и инспирисан садржајем списа, његову скрханост и малодушност замењује „неколико узбудљивих ноћи“ које проводи „преписујући садржај с оригинала који је сваког часа могао да се распе 
у прах и пепео“ (БАСАРА 2013: 64). Спис капетана Квинсдејла се завршава усамљеном реченицом: „Јер, ако је мировање савршено кретање, тако је ћутање савршена артикулација“ (IDEм: 73). У О смислу меланхолије Гвардини говори „о снажној жељи да се живи повучено и тихо.“ Та жеља указује на интимну тежњу душе ка великом средишту [...] жудња да се пронађе сопствено истинско обитавалиште бегом из распршености и враћањем у преданост целини, да се умакне спољашњем постојању и склони се под чедан заклон светилишта, да се избегне површном и убегне у тајну прапочетка (ГВАРдини 2006-2007: 137-138).

Узбуђење и спасилачка ревност које у непознатом преписивачу буди духовна мистерија повести капетана Квинсдејла, по свему другачија од популарних дела „генија петпарачке логике“ Артура Конана Дојла, нас доводи до могућности естетског доживљаја лепог у постмодернистичкој књижевности, до коначне лепоте у меланхоличној потрази за смислом. Раздвајајући духовну од петпарачко-логичке мистерије, непознати преписивач проналази смисао у слању шест примерака повести капетана Квинсдејла у свет, са вером да ће спис пронаћи своје читаоце, који ће даље умножити повест и отпослати је даље. У такође фикционалном предговору Фами o бициклисииима иронично названом Предгоовор йриређивача, приповедач говори о бегу „од туге чији разлог још не [може] поменути“, које га је одвело у Матичну библиотеку у Бајиној Башти и начину на који су њега „пронашла“ дела која су, даље, произвела Фаму о бициклистиима. Ако постоји уметност која судбински себи призива оне којима већ припада, писца је, у тренуцима тескобе, иста призвала у библиотечку ризницу смештену на географској маргини, на место са којег ће, као и девојке срцоликих лица и злаћане косе које у Објави броја 49 Едипа Мас посматра на триптиху Bordando el Manto Terrestre, започети своје ткање, и пустити га у свет. „Бесконачност се посведочује у срцу“ (Басара, 2013: 140), између осталог закључује Гвардини, а непознати преписивач из Фаме о бициклистиима својом вером у моћ аутентичне речи макар на кратко успева да загосподари (бес)коначношћу.

2.3. ПУТАњА МЕЛАНХОЛИЈЕ ЈУЛИЈЕ КРИСТЕВЕ: КНИЖЕВНОСТ И УМЕТНОСТ КАО СуБлИМАТОРИ МЕЛАНХоличнЕ ТУГЕ. Јулија Кристева се у свом есеју Пуйањ $a$ меланхолије бави уметничким стварањем које произилази из меланхолије. Као и Гвардини, Кристева се бави чежњом за лепотом за коју каже да је инхерентна меланхолији, тачније немогућности да се прежали нешто што је било вољено а што је изгубљено. Та бол је иницијатор алхемије сублимације, другим речима трансформације у узвишено:

Многи текстови и многе биографије показују нам колико лепота, иако то није сасвим очигледно, пошто је с правом призивамо како бисмо се њоме борили против зова смрти, дугује искушењу смрти и уништењу како смисла комуникације тако и смисла самог живота (КРистевА 20062007: 179). 
Кристева, дакле, на самом почетку полази од писане продукције, пре свега књижевне, и везује је за идеју лепоте, чија је улога суштинска у борби против метафизичке празнине и ништавила које доноси смрт. Ипак, лепота не стоји као апсолутна супротност смрти и тами ништавила, већ из ње на одређени начин произилази, рађа се као средство борбе из свих искушења која идеја ништавила ставља пред човека. Под ништавилом које прети човеку својом тамом не подразумева се само смрт, немогућност превазилажења коначности, већ и тешкоће превазилажења препрека у комуникацији и удахњивања новог смисла у окамењена значења речи. Кристева овим доводи у везу страшну таму смрти са страшном тамом немогућности комуникације, а обе се налазе у бити човекове потраге за смислом живота.

Пре него што се позабави сублимацијом, Кристева напомиње да се и

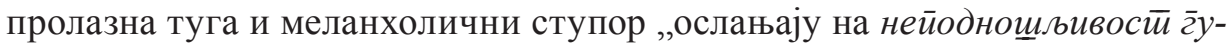
битика и неусиеех означииееља да обезбеди компензаторни излаз из стања повлачења у која се субјект скрива“" (IDEM: 180). Неподношљивост губитка се огледа у неуспеху означитеља - стварности, односно језика - да губитку да смисао, а величина губитка и туга узрокована њиме су толике да се сама стварност „буни против значења“ (IDEM: 181). Књижевна и уметничка продукција се јављају као сублиматор туге узроковане нестабилном, непоузданом стварношћу, као „универзум могућег“ када је означавање у питању, и „свет имагинарног“ се успоставља као „означена туга“ (IDEм: 183). Уметност, каже Кристева, као да указује на поступке који „не преокренувши напросто жалост у манију“ уметнику и зналцу могу да обезбеде „могућност да се на сублиман начин домогну изгубљене Ствари“, примајући од своје потиштености „врхунску, метафизичку луцидност“ (IDEM: 181).

Да би до сублимације из меланхолије могло доћи, неопходан је језик који такав преображај, „ускрсавање“" о коме говори Кристева, може да изнесе. О сличном говори и Ролан Барт у свом делу Задовољстиво у йекс $\bar{u} y$, где као супротстављен тексту који пружа задовољство и/или уживање ${ }^{13}$ види ,фригидан текст“, „пену језика“, језик за који се може рећи да „брбља“ (БАРт 1975: 4-5) ако се језик, као означитељ, не покаже достојним, успевајући да се „напуни смислом“" (КристевА 2006-2007: 183). Код Барта, успешан означитељ/ језик у себи поседује неурозу, или жудњу текста који „мора да ми да доказа да ме жели“ (БАРТ 1975: 7). У корену те жудње коју текст одашиље налази се неуроза о којој Барт говори у контексту страха од немогућности, ослањајући се на дефиницију коју је дао Жорж Батај: „Неуроза је бојажљиво поимање дна немогућег“(IDEM: 6) Текстови „који су написани против неурозе, из окриља лудила, имају у себи, уколико желе да буду читани, нешто мало од неурозе

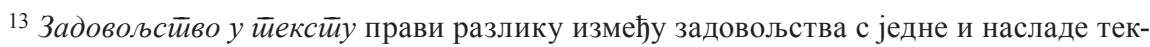
стом с друге стране које се у читаоцу јављају при конзумирању писане речи, напомињући да разлика између задовољства и уживања коју је навео у својој студији не може бити дефинитивна, и да ће увек постојати „неки неразговетни руб“ (4) који не може представљати коначну, поуздану дистинкцију. 
неопходне за очаравање својих читалаца. Ови страшни текстови су ипак заводљиви текстови.“ (IвID.) Даље у тексту Барт их још зове „мистичним“ (IDEM: 58). Управо о оваквом језику говори Кристева док даље у тексту разрађује могућност сублимације меланхоличне туге кроз књижевност:

Могуће је ожалити Ствар, извући се из заточеништва афекта, прићи другој димензији, припојити се уз имагинарно, [...] разрадити губитак. [...] Најпре прозодијом, језиком с ону страну језика који у знак уписује ритам и алитерације семиотичких процеса. Као и кроз поливалентност знакова и симбола, која дестабилизује номинацију и, скупљајући око знака мноштво конотација, нуди субјекту прилику да замисли не-смисао, или истински смисао, смисао Ствари (КристевА 2006-2007: 182).

Губитак се, дакле, разрађује кроз уметност, омогућавањем стварања вишеструких значења, многих конотација. Губитак се на тај начин сублимира - од неимања значења, од бесмисла, уметност пружа могућност да се изроди једно више, метафизичко значење, тј. смисао нечег што је, пре него што је уметнички обрађено, било бесмислено. Лингвостилистички и семиотички процеси су за овај сублимациони процес од кључног значаја и посебно важни за лирско-меланхолични ефекат у постмодернистичкој књижевности, тиме и за Објаву броја 49 и Фаму о бищиклистиима, који се разрачунавају са модернистичким концептима субјективности, душе, утопије, сентименталности и чији је израз заснован на пародичном, метапрозном изразу.

Кристева у Пуйағи меланхолије такође каже да је књижевно стваралаштво, ,једна од пустоловина тела и знакова која сведочи о осећању: о тузи као белегу раздвајања и почетку димензије симбола“"(IвID.). По Кристевој, успешна уметничка сублимација преводи тугу у радост, радост уметничког стварања, а туга је тачка од које креће димензија симбола и фигуративног значења, с тим што постмодернистичка књижевност у великој мери напушта фигуративни језик који тежи миметичком представљању стварности, и окреће се фигурама и тропима који подразумевају поигравања лексиком као и морфолошка и синтаксичко-граматичка одступања од уобичајеног израза у језику књижевног дела. Управо та поигравања и одступања доводе до „суптилне алхемије знакова“, или, даље наводи Кристева:

музикализација означитеља, полифонија лексема, дезартикулација лексичких, синтаксичких, наративних јединица [...] која се сместа доживљава као психичка метаморфоза говорећег бића између две границе бесмисла и смисла, Сотоне и Бога, Пада и Ускрснућа. Те две граничне тематске области, као и њихово истовремено одржавање, предмет су вртоглавог усклађивања у економији имагинарног. Оне су му неопходне, али нестају у тренуцима кризе вредности које се тичу самих темеља цивилизације, и као једино место за ширење меланхолије остављају само способност означитеља да се напуни смислом, као и да се поствари У ништа (IDEM: 183). 
Лингвистички и семиотички процеси о којима говори Кристева (о којима ће бити више речи даље у тексту, у делу који се бави анализом одломака из Објаве броја 49 и Фаме о бициклиситима) у књижевном делу производе „радост као белег победе која се успоставља у свету артефаката и симбола.“ Ова радост је, по Кристевој, радост производње лепог у књижевности, када се лепота „испољава као величанствено лице губитка, преображава га како би му омогућила да живи“ (IDEм: 182). Имагинарно се може упоредити са „искуством меланхолије која се може именовайи“ (IDEм: 183).

2.4. КристоФ Ден ТАНдт: ПостмодЕРНА ЕСТЕТИКА УзВиШЕНог. Говорећи о преласку стања појединца од аутономне индивидуе са личном субјективношћу ка дискурзивној конструкцији обликованој од стране друштва која је способна само за „интензитете“ а не за осећања, Џејмсон, такође у свом делу Postmodernism, or the Cultural Logic of Late Capitalism каже да се еуфоричност, „интензитети“ својствени постмодерном стању најбоље могу „појмити повратком старијим теоријама узвишеног (the sublime)"14 (JAMESON 1991: 6). Кристоф Ден Тандт у свом есеју Invoking the Abyss: the Ideologies of the Postmodern Sublime указује на дела Жан-Франсоа Лиотара и Фредерика Џејмсона као окидаче за поновно буђење интересовања за естетику узвишеног. У овом есеју Ден Тандт се бави постмодерним присвајањем узвишеног и онога што у, идеолошком смислу, из тог присвајања произилази, што је од значаја за овај рад и бављење лирско-меланхоличним језиком као својеврсном дијагнозом одсуства и ништавила у постмодерном добу.

Водећи се постструктуралистичким начелом да ,језик ужива онтолошку предност у односу на субјекте и референте“15 (DEN TANDT 1995: 807), Ден Тандт одбацује Бурково становиште које каже да моћ узвишеног лежи у узвишеном објекту, и полази од тога да је моћ сублимног у самом језику. Језик је тај који има моћ да „преруши невидљиво у видљиво, тоталитет у ограничено, непознато у познато“16 (IDEM: 804). „Реторика узвишеног има способност да даิ лингвистички облик објектима који се не могу представити“"17, што је, верује Ден Тандт, „кључ и продуктивног потенцијала узвишеног, и идеолошког измештања до којег доводи“"18 (IDEM: 805).

Правећи разлику између романтичарског и постмодерног поимања узвишеног, Ден Тандт цитира Џејмсона и каже да „док су романтичарски

$14, \ldots$ a whole new type of emotional ground tone -- what I will call "intensities" - which can best be grasped by a return to older theories of the sublime; ..."

$15, \ldots$...the rhetoric of sublimity can easily be used to support the poststructuralist belief that language enjoys ontological primacy over its subjects and referents."

16 „This ability to disguise the invisible as the visible, the totality as the limited, the unknown as the known..."

${ }^{17}, \ldots$ the ability of the rhetoric of sublimity to give linguistic shape to unrepresentable objects ..."

$18, \ldots$.the key both to the productive potential of the sublime and to the ideological displacement that it brings about." 
песници били опседнути величанственошћу природе, постмодерни уметници могу искусити узвишену језу када контемплирају „струјна кола и мреже неког тобожњег глобалног компјутерског склопа“19 (IDEM: 806). Једном „необичном, религијском тренутку“ у Објави броја 49 претходи загледаност Едипе Мас низ падину калифорнијског предела, „право на огромно пространство препуно кућа које су заједно израсле из тамносмеђег тла“, након којег она помишља на

тренутак када је отворила транзисторски радио да замени батерију и први пут видела једно штампано коло. Уредни низови зграда и улица, виђени из овако оштрог угла, показали су јој се сада са истом неочекиваном, запањујућом јасноћом. Иако је о радиоапаратима знала још мање него о јужној Калифорнији, и једни и други показивали су извана образац хијероглифског осећаја прикривеног значења, намере да комуницирају (Пинчон 1992: 20).

Преплављеност узвишеним Едипе Мас је у исто време и романтичарска - огромно, урбанизовано пространство јужне Калифорније, и постмодерна - технологија која, у недостатку другог смисла, покушава да искомуницира смисао који Едипу превазилази. Провалија не-смисла пред којом модерна јунакиња Едипа Мас стоји, тужна, изопштена и уплашена, гледајући у триптих Bordando el Manto Terrestre на којем је опет провалија у коју девојке срцоликих лица и злаћане косе ткају свет, иста је она провалија из које се јавља лудични и прокажени, Басарин постмодернистички Карло Ружни, провалија коју Ден Тандт назива „узвишеним/сублимним амбисом“ (,a sublime abyss”, 807), „неизрецивом другошћу“ (,the unphrasable otherness”, 811). Сублимни, лирски језик се јавља као формулација искуства светог усред празнине; сунце на хоризонту је „болно“ непосредно пре него што наступи освежење, нешто што је Едипи Мас „сувише споро“ да би могла да осети, на шта њена „прегрејана кожа“" не може да одреагује - чула модерног човека који је сензибилисан на глобалну индустрију забаве, баналне и вулгарне садржаје који побуђују најниже пориве, дереализујући стварност, чији се ефекат осећа јако, и одмах. Религијски тренутак се упоређује са лаганим изговарањем речи, насупрот брзини свакодневнице и ентропичном умножавању информација. Оно што лингвистички израз постмодерног узвишеног чини када „призива бескрајно ништавило“ јесте утемељење становишта да ,,језик у себи има само-одрживу снагу, да је само-потврђујући и само-зачети универзум." 20

19 „Thus, while romantic poets were obsessed with the magnitude of nature, postmodern artists may experience sublime dread when contemplating "the circuits and networks of some putative global computer hookup"..."

$20, \ldots$ what the postmodern sublimity speech act does when it evokes abyssal nothingnesses is to convey the view that language carries a self-sustaining power, that it is a self-validating and self-engendered universe." 
2.5. ОБЈава БроЈА 49. Први пасус ${ }^{21}$ Објаве броја 49 јунакињи романа доноси вест о смрти њеног некадашњег љубавника, и први је, у једном ширем контексту, од многих улазака у тему човекове коначности. У складу са постмодернистичким конвенцијама, Објава нам представља јунакињу очекивано десензибилисану за информацију о болном догађају као што је смрт. Ипак, не до краја. Наратор набраја слике које, неповезано, Едипи пролазе кроз главу непосредно након сазнања о Пирсовој смрти: призор птица које, уплашене, одлећу у непознатом правцу; скровитог места до ког не стиже светлост обнове дана; „сува, неутешна“ мелодија класичне музике. Заједничка црта уланчаних, наоко неповезаних асоцијација се огледа у њиховом језику - иако мора да се помучи „да се осети што пијанијом“, или што погођенијом таквом вешћу, асоцијације које код Едипе, и са тако отуђеним стањем свести, ова вест производи су оно што смо већ спомињали као постмодерну сублимност или постмодерну узвишеност. Парентетични "it seemed forever" из прве реченице у низу, садржећи прилог који означава вечност и уметнут без везника нити било каквих дескриптивних елемената; контраст идеје рађања сунца и недоступности тог чина оку посматрача у другој реченици; персонификација у формулацији „неутешна мелодија“, иако је само човек тај који може бити неутешан у трећој реченици - сви ови елементи акумулирани у низу асоцијација емитују емоционалну затеченост, привремену одузетост застрашујућом идејом смрти и ништавила. Овај низ окончава својеврсно асоцијативно финале 22 које, као и већина фрагмената у Објави броја 49 кроз које провејава лирско, окончава лирско-меланхоличну епизоду тако што се претаче у политичко, пародично, гротескно, апсурдно: Едипа се, у овом случају, присећа интимних тренутака у Пирсовом кревету и својих размишљања, за време истих, како ће се биста једног од највећих америчких капиталиста у једном тренутку стропоштати на њих.

Лирски исказ се у постмодернистичком роману може јавити као заостатак дискурса претходних књижевних епоха које су свој израз градиле на аутентичном доживљају света; искуства ликова у Објави су преплављана имитацијама искуства кроз које, тек понекад, пробије емоција, али никада до краја - ни постмодернистички текст ни његова јунакиња немају услова за пуноћу и заокруживање емоције. Такође, Едипина скоро-религијска искуства у роману у контексту промишљања бесконачности и сила које прева-

${ }^{21}$ Цитат из романа: „Oedipa stood in the living room, stared at by the greenish dead eye of the TV tube, spoke the name of God, tried to feel as drunk as possible. But this did not work. She thought of a hotel room in Mazatlan whose door had just been slammed, it seemed forever, waking up two hundred birds down in the lobby; a sunrise over the library slope at Cornell University that nobody out on it had seen because the slope faces west; a dry, disconsolate tune from the fourth movement of the Bartok Concerto for Orchestra."

22 ,whitewashed bust of Jay Gould that Pierce kept over the bed on a shelf so narrow for it she'd always had the hovering fear it would someday topple." 
зилазе човеково поље деловања и размишљања ${ }^{23}$ исказана су увек лирски. Персонификујући описни придеви, именице и глаголи („, battening, urged sweep”, ,an arrogance or bite to the smog”, „lurked the sea”), уметање слика бескрајних пространстава и епитета изразите емоционалне снаге (,lurked the sea, the unimaginable Pacific"), контраст у набрајању елемената само да би се констатовало да су irrelevant, персонификовање именице Месец („,mоnument to her exile") граде постмодерно сублимно ове слике, или како би Кристева то формулисала, свет имагинарног успева да означи тугу недохватног, нестабилног смисла.

Присуство описних придева снажног поетског набоја који при томе персонификују именицу заузима значајно место у ономе што Стефан Матесич y ecejy „Ekphrasis, Escape, and Thomas Pynchon's The Crying of Lot 49”24 назива поступком замагљивања и тупљења значењске оштрице граматичких и семантичких структура у роману - „неутешна“ мелодија (Пинчон 1992: 5), Едипина коса као „шапутава“ лавина (IDEM: 16), „накарминисани и јавни осмех“ нимфе од обојеног плеха (IDEM: 22), „злоћудно, намерно умножавање“ (IDEM: 116) су само неки од примера придева који персонификују, који објектима приписују особине живих бића, слици дају посебан фигуративни квалитет и поетску снагу док, истовремено, на врло специфичан начин одлажу значење. Одлагање значења и недохватност смисла кроз то одлагање се метафорички манифестује као празнина усред искуства свакодневнице:

Едипа се питала да ли ће и она, на крају свега овога (уколико то треба да се заврши), такође остати само са накупљеним успоменама на трагове, најаве, наговештаје, али не и са самом средишњом истином, која је сваки пут сигурно и сувише светла да би је њено памћење задржало, која увек сигурно сагорева и неповратно уништава своју поруку остављајући преосветљену празнину кад се врати обични свет (Пинчон 1992: 88).

Објава броја 49, аргументује Матесич, је „једва приметно ван фокуса“ и „помало приближна“ у текстуалним елементима који би требало да претендују на тачност и прецизност, што се види у „повремено заборављеном члану или двосмислено употребљеној заменици“, чиме језик романа „еродира сопствени смисао или субстантивни садржај.“ У том процесу, по Матесичу, „текст постаје травестија сопствених тврдњи о истинитости, ткање

23 ,Somewhere beyond the battening, urged sweep of three-bedroom houses rushing by their thousands across all the dark beige hills, somehow implicit in an arrogance or bite to the smog the more inland somnolence of San Narciso did lack, lurked the sea, the unimaginable Pacific, the one to which all surfers, beach pads, sewage disposal schemes, tourist incursions, sunned homosexuality, chartered fishing are irrelevant, the hole left by the moon's tearing-free and monument to her exile."

${ }^{24}$ Маатесичев есеј Ekphrasis, Escape, and Thomas Pynchon's The Crying of Lot 49 преузет из електронског књижевног часописа ПМЦ (РМС, Postmodern Culture) нема пагинацију. 
потенцијално празних значења или непробојна пародична материја.“25 Матесич пренебрегава моћ поетског језика у пробијању „непробојне пародичне материје“, макар то било и герилски, у фрагментима, и када говори о

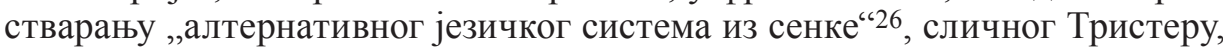
пропушта да примети да непародични језик лиричности може да се третира као његов саставни део, с обзиром на то да провлачење идеје недостатка духовног није противречно тексту који првенствено пародира хиперреалистичну, неаутентичну стварност.

Незадрживе сузе Едипе Мас пред триптихом Bordando El Manto Terrestre сликарке надреалисте Ремедиос Варо ${ }^{27}$ намећу се као најпотреснији сегмент Пинчоновог романа. Тумачи Објаве броја 49 се не слажу око тога да ли је Едипина потрага епистемолошка или, у контексту рађања постмодерног доба у коме је роман настао, само пародија исте, као што тврди Матесич, чиме би и Едипине сузе могле да буду, такође, само пародичне. Емоција је референтно полазиште Едипе Мас у трагању за истином, а језик њених суза je референтно полазиште истраге о томе да ли су оне пародичне, или аутентичне. Самореференцијални приповедач Објаве броја 49 истовремено и меланхоличну и пародичну заплаканост над сликом света испод ког провирује провалија спремно назива „перверзном“, али Едипа Мас прижељкује да сузе наставе да теку и да се никад не осуше, јер јој се свет, установљен

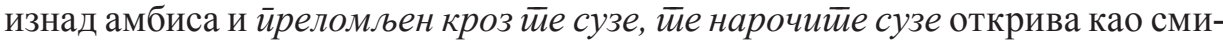
сленији. Матесичева тврдња да у Објави броја 49 нема ништа изван пародије наилази на проблем „суптилне алхемије знакова“ лирско-меланхоличног у тексту, музикализације означитеља и прозодије у језику у који се „уписује ритам и алитерације семиотичких процеса“" (КристевА 2006-2007: 182-183). У оригиналном тексту романа, кључне реченице из наведеног одломка гласе:

25 „The Crying of Lot 49 is also just perceptibly out of focus, slightly approximate in its diction, a feature which can be glimpsed in the above-quoted passage's occasionally lapsed article or ambiguously deployed pronoun. Language begins to erode its own sense or substantive content ... the text becomes a travesty of its own truth-claims, the warp and woof of potentially empty meanings or of an impenetrably parodic "matter"..."

26 "Language (or writing) is strung through the body in the process of becoming the alternative or "shadow" system that Oedipa witnesses only in an exacerbated degradation on the streets of San Francisco..."

27 „In Mexico City they somehow wandered into an exhibition of paintings by the beautiful Spanish exile Remedies Varo: in the central painting of a triptych, titled "Bordando el Manto Terrestre" were a number of frail girls with heart-shaped faces, huge eyes, spun-gold hair, prisoners in the top room of a circular tower, embroidering a kind of tapestry which spilled out the slit windows and into a void, seeking hopelessly to fill the void: for all the other buildings and creatures, all the waves, ships and forests of the earth were contained in this tapestry, and the tapestry was the world. Oedipa, perverse, had stood in front of the painting and cried. No one had noticed; she wore dark green bubble shades. For a moment she'd wondered if the seal around her sockets were tight enough to allow the tears simply to go on and fill up the entire lens space and never dry. She could carry the sadness of the moment with her that way forever, see the world refracted through those tears, those specific tears, as if indices as yet unfound varied in important ways from cry to cry." 
[...] spilled out the slit windows and into a void, seeking hopelessly to fill the void: for all the other buildings and creatures, all the waves, ships and forests of the earth were contained in this tapestry, and the tapestry was the world. Oedipa, perverse, had stood in front of the painting and cried. ... the world refracted through those tears, those specific tears $[. .$.

У цитираном одломку проналазимо различите врсте понављања: епифору, понављање речи или групе речи на крају реченице или реченичне секвенце (,,into a void, seeking hopelessly to fill the void”), анафору, понављање истих речи на почетку реченице или реченичне секвенце (,for all the other buildings and creatures, all the waves, ships and forests"), анадиплозу, понављање исте речи или фразе на крају једног дела реченице и на почетку следећег дела реченице (,contained in this tapestry, and the tapestry was the world”), дијакопу, понављање у које се умеће реч или фраза чиме се појачава поетски ефекат („through those tears, those specific tears”), које све чине саставни део набрајања које води до климакса - Едипиног препознавања таписерије као слике света, и сведоче о великој концентрацији стилских фигура у језику врло кратког одломка који описује садржај таписерије и Едипине сузе које потеку као реакција на њу, укидајући тако, тек на неколико реченица, пародију.

Ипак, ако по страни оставимо лингвостилистичку анализу текста, епизода са триптихом и сузама је, као целина, врло пародична и самореференцијална - касномодернистичко-постмодернистички роман као што је Објава броја 49 у својој структури има ситуацију у којој лик из романа, Едипа Мас, има екстремно емотивну, личну реакцију на једно уметничко дело. Метатекстуални елемент је више него евидентан, уз ироничну поруку да, изгубљена у пролиферацији информација које је заслепљују и збуњују, јунакиња један од својих најважнијих и најизненаднијих увида доживљава управо кроз емотивну реакцију испред једне уметничке слике.

2.6. ФАмА о БициклистимА. У овом поглављу је већ било говора о „перверзним“ сузама Едипе Мас, које крије иза „тамнозелених испупчених наочара“ и истовремено прижељкује да сузе наставе да теку, јер само кроз њих, преломљен кроз сузе, свет има смисла. Једна од песама Јозефа Ковалског из Фаме о бициклистиима (208), иначе песама Светислава Басаре објављених 1977. године у часопису Видици као циклус песама Опис ничега а касније прикључених Фами о бициклистима (ЧАКАРЕвић 2010-2011: 183), има сузе као један од главних мотива, врло близак ономе из Објаве броја 49. Поред суза, мотив је и Град, један од елемената који „ремете пишчеву немогућу мисију“ спознаје духовног (ЈеРемић 2010-2011: 5). Град у Басариној песми се спушта на рамена као терет, из њега проистиче блато које ће запушити „,те издајничке, те скандалозне очи“ које себи допуштају да плачу перверзне сузе човековог ламента над сопственим обесмишљеним постојањем. И мотив града у Објави броја 49 је део истог пропадања; при једном од Едипиних долазака у Сан Нарцисо, приповедач каже да она улази „у град, у заражени град“ (Пинчон 1992: 109). 
Књижевни опус Светислава Басаре се бави искуством светог у модерном добу на много директнији и очигледнији начин. Већ је споменуто да Басара сам, у својим интервјуима и есејима, говори о значају духовног и испражњености модерног света и књижевности од искуства истог. Постмодерна је прогласила превазиђеност таквих питања, а Басарин опус, иако по бројним критеријумима типично постмодернистички, непомирљив је у држању тих питања отвореним. Иако „неретко гневан и саркастичан полемичар, на самој ивици да страст заподенуте распре претвори у сурову карикатуру наше стварности“, указујући на „национална посрнућа, црни и обезбожени рукопис наше новије историје“ (Јеремић 2010-2011: 5) и као такав - друштвено ангажован - по многим критеријумима атипичан постмодернистички писац, Зоран Пановић примећује Басарину „православну меланхолију“ која је често у контрасту са сардоничним дискурсом пародије (БАСАРА, „Свет је из дана у дан све гори“, 2010-2011: 77). Басарино немилосрдно разобличавање стварности се, на први поглед, чини предалеко од меланхолије; Гвардини, ипак, успева да повеже суровост и меланхолију:

Не верујем да би истински меланхолик могао бити природно непријатан: он се превише тесно сродио с патњом. Свакако, меланхолици јесу били непријатни, чак немилосрдни, али такви су постали услед унутрашње невоље, из стрепње, из очајања. Они нису умели да изађу на крај са самима собом. Ништа не постаје тако окрутно као очајање, које више не зна себи да помогне. [...] Ово нас, пак, приближава средишњој вредности меланхолије: у њеној крајњој суштини, она је чежња за љубављу. За љубављу у свим њеним облицима и у свим њеним ступњевима, од најелементарније чулности до узвишене духовне љубави (ГвАРдини 2006-2007: 138).

Ни Басарини коментатори ни Басара сам ни у једном тренутку не превиђају тугу и патњу као елементарни део његове прозе. У интервјуу са Аном Лучић поводом превода романа Кинеско иисммо на енглески, Басара је подвукао значај туге и егзистенцијалног очаја са чином писања:: „Ни данас се не смејем кад пишем. Писање - и уметност генерално - има много више заједничког са тугом“" (БАСАРА, Иниеервју са Свейиславом Басаром, 2010-2011: 163). Чакаревић истиче речи једног од Басариних приповедача који „песнике рангира по патњи коју вуку за собом и по презиру који испољавају према свету и околини“, напомињући да се то, иако је књижевна реплика, „не сме схватити као пука фраза. [...] Наоко успут изречену класификацију није могуће наћи ни у једној од стандардних поетика“" (ЧАКАРЕвић 2010-2011: 191). Пуриша Ђорђевић управо као највредније код Басаре види „када је проговорио: Имам тридесет и седам година и неколико књига иза себе у којима сам покушао да решим своје унутрашње противречности, да се ослободим тескобе и меланхолије. Без успеха“" (ЂоръЕвић 2010-2011: 230).

У контексту хиперреалног, преплављености конструкцијама и наративима који претендују на истину, у свету који је изгубио стабилно значење управо кроз покушаје да се установи једна, истинска и права истина, што 
је увек пут ка окамењивању и објективисању, Фама о бициклистиима поручује да се само кроз разбијање, кроз „извештај о неаутентичности живљења савременог човека“" могу начинити пукотине, мали пролази ка великим увидима-ка метафизичком, оностраном. Басарин роман отвара ове пролазе кроз „неспутаност слободне литерарне игре“ (ПАнтић 2010-2011: 93) која подрива канонизоване књижевне моделе. Ипак, нешто издваја „списе“ приписане краљу Карлу Ружном и капетану Квинсдејлу, у одређеној мери и песме Јозефа Ковалског од делова које приповеда мајордом Гросман, Херберт Мајер, или Сава Ђаконов. У „списима“ из Фаме о бициклистиима препознају се различити стилови, који су пре свега зависни од приповедачког гласа - неки гласови, и језик којим приповедају, пародични су проводници доминантних дискурса, прича које претендују на искључиву истинитост и веродостојност, док су, пак, други субверзивни извори неких другачијих, алтернативних ,историја“.

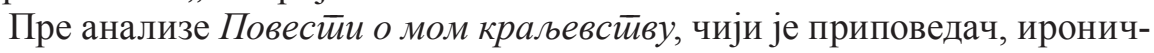
но, краљ који пародира, чак се подсмева свакој идеологији иако би, по свим конвенцијама, требало да буде на бранику доминантног дискурса, осврнућемо се на језик управо оних делова романа чији језик имитацијом и формалном озбиљношћу пародира доминантне дискурсе. Повести о ђаволским двоколииама мајордома Гросмана је један од њих; пародија идеолошко-дисквалификујуће обзнане о делању противника, текст који, без правог основа и аргументације, клевеће неистомишљенике система има стабилну синтаксичко-семантичку структуру, уз глаголска времена која су архаична, што исказу даје епски тон, и мноштво негативних описних придева и прилога: бициклисти неойисиво хуле на Бога, направу јавно и бесрамно возе улицама Париза, бицикл је Ђавоља и сойонска направа, ђаволска двоколица, наойака работа, јатак Двоточкаша/припадника реда Мале браће је ойак и йокварен човек, док је Инквизитор честиит. . Дружина је ђавоља а њихова безакоња нечувена, издржљивост Мале браће при мучењу је резултат йакосне радости коју Сотона налази у „кварењу богоугодних дела“ (БАСАРА 2013: 47-53). Представљајући неаргументовани суд доминантног дискурса, придеви и прилози Повестии о Ђаволским двоколицама су празни; једини доказ да је све непобитно тачно, доказ да је направа „надахнута Сотоном који све наопако чини“ је тај да је то мишљење засновано на основу онога што преовлађујући наратив третира као непобитно тачно. То је и својеврстан метапрозни коментар свака дескрипција у жестоком идеолошком покушају наметања истине заврши као промашај и празнина.

Придеви које користи приповедни глас Карла Ружног су такође негативни и дисквалификујући, и њихова функција је такође метапрозна, али на потпуно супротан начин, с обзиром на то да исказују веома снажан презир према свим покушајима да се знање и смисао објективишу у јединствену, апсолутну истину. У његовој приповести чињенице су ващиљиве, за научнике (,„деценте“) као што је Гросман, чија душа је смрдљива, каже да мисле да могу 
„Прокријумчарити истину и тиме у некој буђавој књизи заслужити своје скромно место“, историја је кукавна, чула су йричава, роман је безначајан, а претендовање на хронологију и историјску тачност је „историјска заблуда“, којом је краљ Карло Ружни опседнут (Басара 2013: 23-45).

За разлику од Гросмана, краљ Карло Ружни је сардонични меланхолик, луцидан и мрачан, а језик његовог приповедања одраз „мистичне наде у поправљање света путем његовог уништења“ (IDEм: 39). Реченична структура је стабилна, али у значењском смислу заснована на парадоксу, „формирању лажног каузалитета (или „фингирању узрочно-последичног низа)“(ДАмЈАнов 2010-2011: 85), због ког је порука коју та стабилна реченична конструкција шаље иронична и пародична, а њена веродостојност субвертирана:

Sancta simplicitas! Онај ко пристаје да буде убијен и покраден, има право да убија и краде. Нико други. Пошто ја пристајем да будем и убијен и покраден, убио сам Марго и њеног љубавника, и ни то није помогло. Ето, наставили су да ме варају, и вараће ме док је света и века (БАСАРА 2013: 32).

Новица Милић овакво извртање значења тумачи као вид узглобљавања реченице при којем „паратакса преузима на себе хипотаксу како би се изнутра разградила“" (Милић 2010-2011: 203), другим речима реченица која

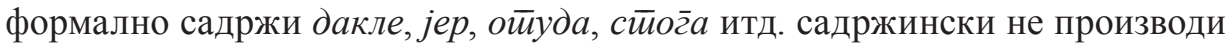
логички закључак који употреба таквих везника обично претпоставља. Приповедање краља Карла Ружног садржи и контрастне односе у оквиру реченица које се огледају у присуству речи које припадају различитим регистрима, као што је случај са речима диспут и наждеру у реченици: „Онда је газда прекидао наш диспут и теологија је морала да сачека да се великаши наждеру“ (БАСАРА 2013: 22). Лирска меланхоличност се, у Предг̄овору йриређивача и Повесиии о мом краљевстиву, усред таквог језика формира појачаном употребом придева који, као и у претходним случајевима, имају негативну форму али немају негативан предзнак, другим речима немају негативну конотацију већ означавају појмове који остају с оне стране људског

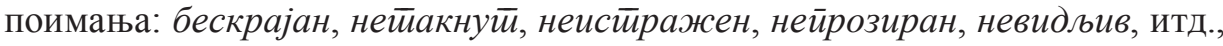
затим набрајањима, преплитањем стилских фигура као што су ономатопеја и анафора:

Лицемер. Мисли да не знам да у потаји, невидљивим мастиилом,

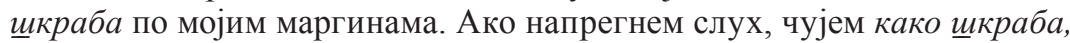
како грребе по површини историје, како оставља своје мрље, гоњен безумном жељом да не ишчезне из памћења света (IDEм: 28).

Присутна су понављања, истих именица у различитим падежима, глагола у различитим глаголским временима и различитих врста речи истог корена, равномерно или неравномерно распоређених: 
Ниједна вера не може изменити свет и ниједна чињеница никада не може оповргнути веру. Тако ће писати Освалд Шпенглер у сумрак једног будућег клања. Узалуд ће йроћи стиойине гоодина; ни тада то никоме неће бити јасно. Године иролазе узалуд; то је прва премиса овог поглавља ПОВЕСТИ. Хиљаде узалудних гоодина (ІDEм: 33).

Фигура понављања са сличним дистрибутивним обрасцем и седмоструком употребом различитих речи које означавају умирање и смрт ствара изразито снажан ефекат меланхоличног осећања празнине и у следећем одломку:

[...] одсуство [Гросмановог] присуства омогућиће да коначно рашчистим једну ствар: јесмо ли мрйви. Тиме не мислим - умрли. То је чињеница. Датуми наше смрӣи ствар су, како се у ово време сматра, врло далеке прошлости. Умрли смо, умрли, у то не може бити сумње. Чак и да сећање изневери, ту је Гросман; његове посете грробниции у коју сам га ипак сахранио. Свашта се догодило на лицу света док смо сањарили неколико часака. Али то ме не испуњава чуђењем ни гађењем. Нисам ли све то знао? Пре свега, ваља ми решити проблем нашег онтолошког статуса“" (IDEM: 299).

У Фами још фигурирају инверзија (,Бескрајне су тајне провинцијских библиотека.“), компарација (, ,.., као у паклу, ...“), „Као што се злато не тражи у јувелирницама ...", а посебно је интересантно присуство алитерације:

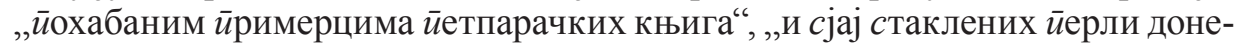
кле $\bar{u}$ росијава кроз йомрчину“ (Idem: 17-22). Од значаја је приметити како алитерација често неприметно појачава снагу чак и имена књижевних ликова и значајних појмова у роману: краљ Карло, капетан Квинсдејл, Гросманова г̄робница. „Предговор приповедача““ као фикционални сегмент романа има снажан лирски набој, коме доприноси и једна од ретко поетичних метафора у роману:

Предајући читаоцу овај зборник у руке схватам да сам пре неколико година, трагајући за шареним камичцима набасао на бисер, али и то да је бисер у очекивању достојног власника нашао недостојног, који га умножавањем у недопустиво великом броју примерака претвара у стаклену перлу. Једино оправдање је да у нашем времену, које спада у касну јесен гेодине гоодина (о чему пише капетан Квинсдејл) и сјај стаклених перли донекле просијава кроз помрчину што се згушњава над хоризонTOM (IDEM: 18).

Реч која и даље просијава светлошћу, као Басарине светлуцаве перле, дирљива је реч која, као перле, просијава кроз ноћ пародичног, аутореференцијалног текста. Чини се да дистрибуција лирско-меланхоличних фрагмената у тексту какав је Фама о бициклистиима на одређени начин корелира са Басариним освртом на „протурање“ субверзивних, програмских текстова као што је његова Мейафизика йрозе у свейлу йройастии Зайада, у јавност: 
Као што се зна, тада [1984. или 1985.] су комитети још увек радили пуном паром, па кад је неко хтео да каже нешто против комуниста, онда се то чинило тако што се неколико пасуса антикомунизма уметало у пет-шест шлајфни тешке метафизике која је спречавала цензоре да доспеју до „опасних места“ ( БАСАРА, Тумарање йо бесйућу, 2010-2011: 71).

У Фами је, на сличан начин, тек овлаш и понегде, расута меланхолија, као део мамца којим свако дело тражи свога читаоца. Фама проповеда идеју о повратку духовности на сличан начин на који и Еванђеоски бициклисти ружиног крста остављају свој траг кроз историју - стварајући у читаоцу неверицу да се све то може бити истина, узроковану укупном пародијом и праксом деидеологизације свега што се нађе на путу.

3. ЗАКључАк. У уводу овог рада напоменуто је да су постојале извесне тешкоће у проналажењу теоријског утемељења за испитивање простора који постмодернистичка, метапрозна књижевност оставља за естетско уживање у лирско-меланхоличном језику. Под естетским уживањем овде се мисли на читалачку интеракцију са текстом која није првенствено деконструктивна и која не представља критичко-пародично поигравање са претходним дискурсима, већ меланхолични осврт на постмодерну празнину и човекову тегобну смештеност у исту. У закључку своје књиге Russian Postmodernism: New Perspectives on Post-Soviet Culture, Михаил Епстајн, говорећи о стању у руској књижевности, истиче потребу за „новом искреношћу“(,new sincerity”) која се код руских постмодернистичких писаца јавила још крајем осамдесетих година двадесетог века. Нова искреност, објашњава Епстајн, трансцендира ироничну дистанцу, „знаке навода“ (који су неодвојиви од пародије). Писац који ствара са „новом искреношћу“ не прибегава идентификацији са својим јунаком (што би била одлика „старе искрености“), већ развија свој поетски/приповедни глас као синтезу претходних текстова (текстова који су „под знацима навода“) и онога што доживљава као свој индивидуални глас. Епстајн истиче да овакав приступ доводи до феномена који би се могао назвати „транс-лиричност“ („trans-lyricism”, термин Дмитрија Пригова), која је страна и модернизму и постмодернизму (EPSTEIN 1999: 457).

Испитивањем језика Објаве броја 49 и Фаме о бициклистиима, можемо аргументовати да се трагови лирског и меланхолије јављају и у (пост)модернистичкој књижевности као израз одсуства духовног и идеје центра у капиталистичко-потрошачком друштву, и егзистенцијалне језе као производа „искуства празнине [...] човека као бића осуђеног на бесмисао и неаутентичност постојања“ (Илић 2010-2011: 106). Нестанак индивидуалног субјекта, сопства које је, као такво, имало способност да осећа, укинуло је субјективност која је могла да изрази аутентично осећање. Постмодерни појединац, формиран у друштвеним и културним околностима испосредованог, репродукованог и комерцијално рабљеног искуства, није више способан да осећа на начин на који је то раније било могуће, нити да, последично, аутентично 
осећање језички изрази. Осећање празнине и језичка осујећеност производе носталгију за аутентичним искуством и изразом, а меланхолија се јавља као жудња за апсолутом, која је у корену сваког стваралаштва. Тумачење Објаве броја 49 и Фаме о бициклистимла се у овом раду темељи на анализи одломака из романа који показују значајно присуство стилских фигура чији лирско-меланхолични ефекат поништава пародично деловање у наведеном сегменту текста. Лирско-меланхоличне епизоде се јављају као жудња за стабилним значењем, за метафоричком пуноћом постојања која би постојала изван текста, а уместо ког, у Објавиним и Фаминим друштвено-историјским и књижевним околностима, постоји само духовна празнина постмодерног света.

Разматрање постојања лиричности у постмодернистичком тексту отвара питање да ли је постмодерно стање друштва, а самим тим и његова књижевност, поред све своје пародичности и самореференцијалности које, како је ово истраживање показало, резонирају са самољубљем и егоцентричношћу које то друштво негује, икада смогло снаге да се у потпуности одрекне могућности да ипак постоји нешто изван текста, нешто што би, као изванредна метафора, језик лишен деконструктивних намера, имало моћ да обухвати Смисао.

\section{ИЗВОРИ И ЦИТИРАНА ЛИТЕРАТУРА}

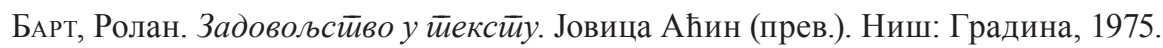

БАСАРА, Светислав. Енигма постмодернизма: шта после. Басара. Бранко Кукић (ур.). Чачак: Градац, 2010-2011, 61-62.

БАСАРА, Светислав. Интервју са Светиславом Басаром. Интервју водила Ана Лучић. Басара. + Бранко Кукић (ур.). Чачак: Градац, 2010-2011, 163-164.

БАСАРА, Светислав. Свет је из дана у дан све гори. Интервју водио Зоран Пановић. Басара. Бранко Кукић (ур.). Чачак: Градац, 2010-2011, 76-77.

БАСАРА, Светислав. Тумарање по беспућу. Интервју водио Дејан Илић. Басара. Бранко Кукић (ур.). Чачак: Градац, 2010-2011, 64-73.

БАСАРА, Светислав. Фама о биииклистиима. Београд: Лагуна, 2013.

Гвардини, Романо. О смислу меланхолије. Душан Ђорђевић Милеуснић (пев.). Меланхолија. Бранко Кукић (ур.). Чачак: Градац, 2006-2007, 134-140.

ДАмлАнов, Сава. Кинеско огледало нестаје by night, или како „стрефити“ афричког пингвина. Басара. Ур. Бранко Кукић. Чачак: Градац, 2010-2011, 83-92.

Ђоръввић, Пуриша. Есеј о Басари. Басара. Бранко Кукић (ур.). Чачак: Градац, 20102011, 229-231.

Илић, Дејан. Искуство светог и искуство празнине у прози Светислава Басаре. Басара. Бранко Кукић (ур.). Чачак: Градац, 2010-2011, 106-122. 
ЈеРЕмић, Зоран. Басара by night. Басара. Бранко Кукић (ур.). Чачак: Градац, 2010-2011, 5.

КристевА, Јулија. Црно сунще: дейресија и меланхолија. Младен Шукало (прев.). Светови, 1994.

КристевА, Јулија. Путања меланхолије. Превела Александра Манчић. Меланхолија. Бранко Кукић (ур.). Чачак: Градац, 2006-2007, 179-183.

Милић, Новица. Grande confusão. Басара. Бранко Кукић (ур.). Чачак: Градац, 2010-2011. 201-207.

ПАнтић, Михајло. Светислав Басара: гротескна хипербола света. Басара. Бранко Кукић (ур.). Чачак: Градац, 2010-2011, 93-95.

Пинчон, Томас. Објава броја 49. Давид Албахари (прев.). Светови, 1992.

СтАнолевић, Добривоје. Постидилична сликовница Светислава Басаре. Басара. Бранко Кукић (ур.). Чачак: Градац, 2010-2011, 80-82.

ЧАКАРЕвић, Марјан. Фаме о Б.: Писмо Бранку Кукићу. Басара. Бранко Кукић (ур.). Чачак: Градац, 2010-2011, 181-196.

Altieri, Charles. The Powers and the Limits of Oppositional Postmodernism. American Literary History, Vol. 2, No. 3, Oxford University Press, 1990, 443-481. <http:// www.jstor.org/stable/489949> 27. 7. 2015.

Bertens, Hans. The Idea of the Postmodern: A History. London and New York: Routledge, 2005.

Den Tandt, Christophe. Invoking the Abyss: the Ideologies of the Postmodern Sublime. Langues et littératures modernes - Moderne taal-en letterkunde, tome 73, fasc. 3. Bruxelles: Revue belge de philologie et d'histoire, 1995. 803-821. <http://www.persee.fr/doc/rbph_0035-0818_1995_num_73_3_4038> 10.6. 2016.

Epstein, Mikhail, Aleksandr Genis, Slobodanka Vladiv-Glover. Conclusion. Russian Postmodernism: New Perspectives on Post-Soviet Culture. New York and Oxford: Berghahn Books, 1999.

Jameson, Frederic. Postmodernism, or the Cultural Logic of Late Capitalism. Duke University Press, 1991.

Mattessich, Stefan. Ekphrasis, Escape, and Thomas Pynchon's The Crying of Lot 49. Postmodern Culture. $<$ http://pmc.iath.virginia.edu/text-only/issue.598/8.3mattessich. txt.> 25. 5. 2016.

Hutcheon, Linda. Irony, Nostalgia, and the Postmodern. Volume 6 of the Proceedings of the XV Congress of the International Comparative Literature Association "Literature as Cultural Memory.” Ed. Vervliet, Ray mond and Annemarie Estor. Amsterdam and Atlanta, GA: Rodopi, 2000, 189-207.

Hutcheon, Linda. The Politics of Postmodernism. Routledge, Taylor \& Francis e-Library, 2001. 
Jovanka D. Kalaba

\section{LYRICAL MELANCHOLIC DISCOURSE IN POSTMODERN NOVEL: THOMAS PYNCHON'S THE CRYING OF LOT 49 AND SVETISLAV BASARA'S THE CYCLIST CONSPIRACY}

Sum mary

The paper deals with the possibility of lyrical and melancholic language in two postmodern novels, The Crying of Lot 49 by Thomas Pynchon and The Cyclist Conspiracy (Fama o biciklistima) by Svetislav Basara. The paper argues that lyrical melancholic fragments, scattered in predominantly parodic and self-referential discourse of postmodern prose narratives, appear as a kind of linguistic formulation of the absence of the spiritual and the metaphysical from the life of the (post)modern individual. The novels' parodic and self-referential techniques erode the traditional literary conventions, at the same time eroding the novels' protagonists' sense of understanding of the worlds they inhabit. Postmodern groundlessness makes the segments of the novel in which the protagonists deliberate the world and the self highly melancholic. The language of the novels, which, as all postmodern literature, leaves little or no room for pleasure and identification, contains lyrical fragments that are seen as the linguistic overcoming of deep melancholic discomfort: giving meaning to the meaningless world. The melancholic element is linked to the sorrow for the lost language and the lost context in which heroic, courteous, romantic, highly formal etc. discourses could have their authentic existence, outside of parody and self-referential discourse.

Postmodern theorists and literary critics talk about the feelings of nostalgia and melancholy as fundamental elements in every creative process. Linda Hutcheon focuses on nostalgia as an expression of dissatisfaction with modern circumstances, stressing that only combined with irony can nostalgia avoid becoming regressive and revivalist. Ironized nostalgia turns to the idealized past in a manner that allows looking into the past without ever forgetting that returning to it is fundamentally impossible. Romano Guardini and Julia Kristeva emphasize the importance of the melancholic discomfort in literary production, seeing it as potent, constitutional sorrow that triggers what Christophe Den Tandt calls the postmodern sublime, the linguistic overcoming of what at first seems irreducible to language.

This paper approches the two novels' potentiality of style in order to examine the manner in which the lyrical and the melancholic is produced in The Crying of Lot 49 and The Cyclist Conspiracy. The Crying of Lot 49, the text which, to a great extent, both thematically and formally belongs to the modernist tradition, builds its lyrical potential on metaphor, comparisons and descriptive adjectives of a "blurry", deferred meaning, with a significant presence of figures of repetition. The Cyclist Conspiracy, on the other hand, as a paradigmatic postmodern text, owes its lyrical charge mainly to repetitions, contrasts and inversions, as well as a specific use of negative adjectives, while both texts have a highly pronounced humorous slant.

Универзитет у Крагујевцу

Факултет за хотелијерство и туризам

jovanka.kalaba@yahoo.com 